an expression of resthetic principles, as, for example, in the better-known specimens of West African sculpture, seemed to attach a false value to characters which were, in historical perspective, faults of technique rather than an outcome, conscious or unconscious, of any theory of artistic balance, selection or composition. A saner method of approach to the products of primitive art was illustrated by Dr. Leonard Adam in a recent lecture delivered before the Royal Society of Arts ( $J$. Roy. Soc. Arts, June 28, 1940) in which he briefly directed attention to certain of the main principles of primitive art which emerge from its study in accordance with the evolutionary or cultural methods elaborated by the late Dr. A. C. Haddon, Prof. Franz Boas and others. Incidentally Dr. Adam stressed the interest and importance of the art of the American Indians of the north-west coast of America, which has suffered neglect in favour of the culturally less illuminating art of Africa.

The future of primitive art is, when properly understood, no less interesting than its past. It is true that in many parts of the world European impact has brought about degeneration; but experience in West Africa has shown that this is not inevitable. It was pointed out by Dr. Adam that modern ethnographical studies have demonstrated that early observers tended to overstress the static element in primitive culture. Art, however, like other cultural factors, has been subjected to a continuous process of change. Much of the so-called primitive art is in fact both highly sophisticated and 'evolved'. The result of such European guidance in West African education as has been formulated with understanding of native modes of thought has been to produce a native school of art, which not only in the traditional art of wood-carving, but also in other branches of artistic activity such as painting, is thoroughly African in conception, feeling, and atmosphere. It has survived or overcome the break with the social and religious factors upon which African art depended, but which vanished, or are vanishing, before European contacts. Hence, as Dr. Hanns Vischer pointed out from the chair on this occasion, this development indicates a line of advance in the present deplorable state of education in Africa-a beginning "to make grow . . . to liberate something which has been stifled under the thick crust of foreign knowledge acquired without real understanding".

\section{Rufford Village Museum}

RUFForD Village Museum, which was opened at Rufford Old Hall, a National Trust property in West Lancashire in July of last year as: "A Museum of Folk Culture and Industry : To illustrate and capture the spirit of the countryside" (to quote its constitution) is being developed by the honorary curator, Mr. Philip Ashcroft, jun., to be "an example for other districts to follow, so that in the future, each village or group of villages will have a museum to represent their life, history and culture". In addition to Baron Hesketh's extensive collection of old armoury and other relics of medieval life, Mr. Eric Hardy has drawn up lists of the local fauna and flora which will be exhibited above photographs, drawings, diagrams, etc., of wild life to encourage people to preserve as well as observe the wild life of the parish. This happens to be unusually rich, for the flora includes flowering rush, flowering fern, arrowhead, yellow waterlily, water soldier, bladderwort and nearly a thousand other plants; there is a list of twentytwo mammals for the parish and F. A. H. Hall and E. Hardy have drawn up a list of 101 bird records, including sixty nesting species - a third of the British records. The Museum itself is a historic old timbered hall, the restored part of which dates from the seventeenth century.

\section{Research in Social Relations in Industry}

Mr. H. VALDER, of Hamilton, New Zealand, has endowed for five years a research fellowship in social relations in industry at Victoria University College, Wellington, N.Z. Mr. Valder has himself done original work in investigating problems of industry, more especially those concerning the relation of capital and labour, and he believes that the work can be carried further by a man with scientific knowledge. To ensure that the investigator may be independent, the work is to be done under the ægis of the Victoria University College Council, and the appointment will carry with it the privileges of a professorial chair in the College. The salary offered is $£ 1,000$ a year (N.Z. currency) for five years. Applications from candidates should be sent to the Registrar of the College.

\section{Forestry Investigations in India}

THE activities of the Forest Research Institute at Dehra Dun, India, are summarized in a report entitled "Forest Research in India and Burma, Part 1, 1938-39". The work of the various branches of the Institute is described and the report forms a record of a large amount of useful work carried out in the interests of the State. Apart from research work, an enormous number of queries relating to the utilization of various forest products has kept the staff extremely busy during the year. It is noteworthy that all the provinces of India now employ an officer solely dealing with sylvicultural problems. The co-ordination of this work and advising on statistical requirements, in order to make the best use of the researches going on, have taxed the Sylvicultural Branch of the Institute severely.

It is not possible to make more than passing reference to a few of the programmes of work that are being carried out. The destruction of timbers by termites and by fungi is one of great importance, and this work is closely linked with problems of the seasoning and preservation of woods of many kinds. The paper-pulp section is another activity of great importance and promise, and questions connected. with the manufacture of paper and plywood were probably the most numerous of all. The report itself, it may be added, is printed on paper made at the Institute from Saccharum arundinaceum. The cultivation of drugs is another aspect of work that 